Discourse and Communication for Sustainable Education, vol. 8, no. 1, pp. 64-80, 2017

\title{
Ecology Approach in Education and Health Care
}

\author{
Rūta Bogdanova, Maruta Šiliņa and Ruta Renigere \\ Riga Medical College of the University of Latvia
}

\begin{abstract}
In the 21st century, numerous complex challenges in education and health care have come to the fore, among them: 1) how to implement the ecological approach in the education process and health care practice; 2) how to implement study programmes in line with the education trends for sustainable development and the process of formation and development of the ecological competence.

The results of this research refer only to the content analysis of the essays written by the first and second year students of the programs in Nursing and Medicine on completing the study course The Ecological Approach in Patient Care. To increase the credibility and validity of the obtained results of the content analysis, the triangulation method has been applied to include quantitative and qualitative data. The research has looked into the concept of ecology, its application and importance in developing the ecological consciousness of students during their transformation from I-Ego to I-Eco in the process of developing their ecological competence (Salite, 1998).

Keywords: sustainability/sustainable development in health care, education for sustainable development, ecological approach, ecology of human development, deep ecology and ecosophy.
\end{abstract}

\section{Introduction}

The ecological approach in education process and health care practice must be looked at as a varied and complex system of learning, socializing and culture that consists of many different subsystems. It is a way to implement sustainable development of education and sustainability/sustainable development in health care promoting unity and congruence of science and health care. The ecological approach in education and health care practice refer to the value-oriented transformation process of students from $I-E g o$ to $I-E c o$ in their life activities and systemic thinking in social, education and health care environment, complementing the professional code of ethics (Salite, 1998).

The ecological approach in the process of education and health care creates a multilevel interdisciplinary system. It is characterized by universal, interdisciplinary, integral, social and cultural context. By blending experience and creative activities, it develops an integrative combination of competences. The interconnectedness of this system allows 
for defining the relationship and interaction between human, environment and society. It develops professional conduct and awareness about the importance of knowledge in seeking solutions for ecological issues. The ecological approach in the education process of students and in health care practice relates to self-organization, creativity and ability to deal with unexpected and complex ecological issues and situations in a multilevel environment

The ecological approach in the process of education and health care should be viewed in the context of lifelong learning and further improvement of life activities. It is important to point out Mollenhauer's (Klaus Mollenhauer, 1928-1998) opinion on the human ability to integrate into society, which demands the liberation of the subject, that is, in order to be able to make an independent and responsible decision and to be able to act freely and independently, the subject must be liberated from the conditions that limit and inhibit their activity in society (Mollenhauer, 1973).

Evaluation of many insights and research outcomes in a variety of publications has led to the definition of a hypothetical assumption that the formation and development of the ecological competence in education and health care can be promoted if formal, informal and non-formal education is based on the ecological approach (Salite, Drelinga, Iliško, Zariņa, \& Oḷehnoviča, 2016).

The ecological approach in education and health care practice is characterized by the principles developed as a result of theoretical research and the components of professional competence. From a systemic perspective, this forms the ecological competence in the social and educational environment and through experiences in health care.

The ecological approach in education and health care is built upon three basic building blocks:

1) Education for sustainable development and sustainability/sustainable development in health care practice;

2) Bronfenbrenners' ecology of human development theory;

3) Deep ecology and ecosophy by Naess.

\section{Ecology of Human Development in the Education Process and Health Care}

The ecology of human development based on the research and insights of Bronfenbrenner and other scholars makes a significant methodological foundation for the formation of the ecological principles of students.

Bronfenbrenner, the author of the theory of the ecology of human development, relates his philosophy to the scientific study of the progressive mutual accommodation between an active, growing human being and the changing properties of the immediate settings in which the developing person lives. He believes that this process is affected by relations between these settings and by the larger contexts in which the settings are imbedded (Bronfenbrenner, 1979, Definition 1).

In the context of the present research, the growing person is a student in the process of education and health care. During this process, a student - the growing person acquires a more extended, differentiated and valid conception of the ecological environment and becomes motivated and able to engage in activities that, in form and content, sustain, or restructure that environment at levels of similar or greater complexity, or reveal the properties of that environment (Bronfenbrenner, 1979, Definition 7). 
There are three main types of interaction identified between a developing, growing person and the ecological environment and setting:

1) a person keeps changing and accommodating to the environment that does not change;

2) a person changes the environment without changing himself or herself;

3) a mutual interaction, accommodation and development between a person and the environment.

The significant concept of environment receives a special emphasis in the summary of the main concepts and insights of systemology. Every system is characterized by its internal and external environment. Its structure is a display of its parts forming the system. The internal environment is a whole made of its components; the external environment, in its turn, is everything that the respective system does not comprise. Every system is an externally designed internal environment separated by the system's border surface (Broks, 2000; Salìte, Drelinga, Iliško, Zariņa, \& Oḷehnoviča, 2016).

Transforming the definition and propositions put forward by Bronfenbrenner that there is a correlation in every place, a theoretical foundation for a dyadic correlation between the education process of students and health care practice can be established. When students cooperate and participate in the education process and health care practice, observation dyads and dyads of joint or shared activities are developed (Figure 1).

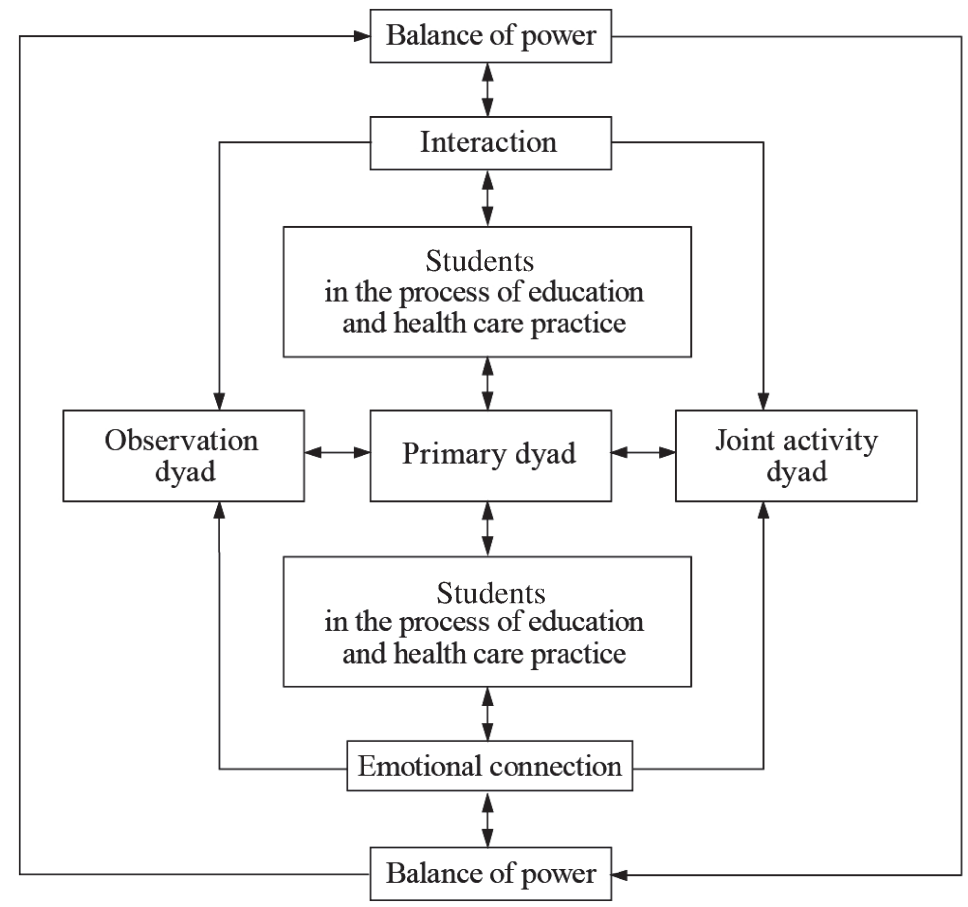

Figure 1. Dyadic relationships of students in the process of education and in the environment of health care practice

In the education process and health care practice of students, dyadic relationships provide critical context for individual development. They also provide the basic construc- 
tion of a microsystem improving on a broader range of skills in interpersonal structures, triads, tetrads etc. To promote the psychological development, a dyad acquires different functional forms in the education process and health care practice of students emphasizing the potential for interaction and development.

An observation dyad in the process of a favorable interaction shapes a mutually supportive emotional attitude among students during the process of education and health care practice. An observation dyad plays a significant role in the process of education and health care practice of students as the obtained knowledge and skills do not always correspond to the real life health care situations.

By paying attention to and being aware of the shown interest, students can develop an attitude, motivation and appropriate behaviour, for example, by actively participating in the study process, joining in discussions, expressing their opinion based on their knowledge and experience, and by being able to analyze and assess any problem situation critically (Bakutytè, Ušeckienè, \& Iliško, 2016).

A dyad of joint or shared activities is characterized by the balance of power in the subject - subject relationship - not competing, but cooperating and participating. Dyads of joint or shared activities in the process of education and health care practice can be characterized by the application and use of the theoretical knowledge in health care practice. During their clinical practice, students acquire health care skills. Attitude, motivation and appropriate behaviour - all of these affect the dyad of joint or shared activities.

In Bronfenbrenner's bio-ecological theory of human development, the concept of an endosystem is replaced by the concept of the growing or developing person mentioned in the definitions. The concept of a student in the process of education and bealth care practice is applied respectively. To demonstrate the development of a student that has occurred during the process of education and health care practice, it is necessary to establish that a change produced in the conceptions and/or activities of a student carries over to other settings and other times. Such demonstration is referred to as developmental validity (Bronfenbrenner, 1979, Definition 9).

From a systemic point of view, an endosystem is the core of a system. The growing/ developing student in a social, educational and health care environment characterized by a physical, social, psychological and spiritual affiliation with this environment is like an open systemic whole in an ecological environment (Figure 2).

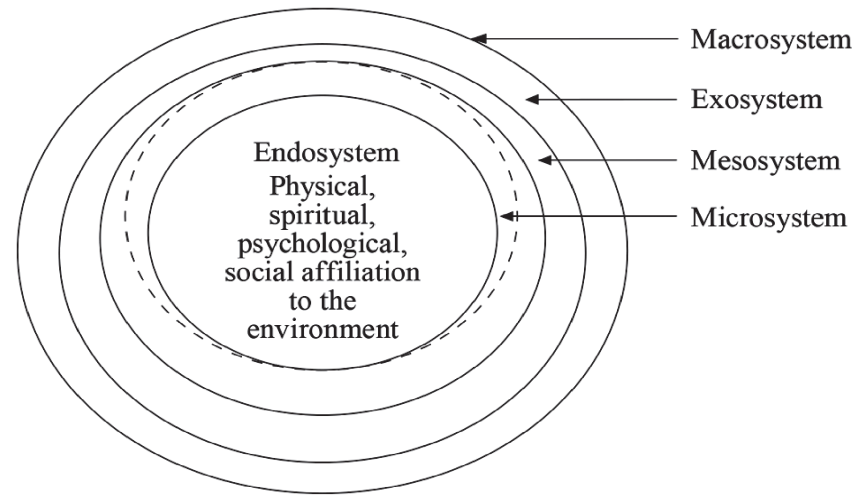

Figure 2. The core of a system (endosystem) in a multi-level ecosystem 
This approach corresponds to the requirements put forward by Bronfenbrenner and Moriss who insist on researching simultaneously both - an individual and the environment. It is also in line with Lerner's view about the related systems and merging of systems (Bronfenbrenner, \& Moriss, 2006; Lerner, 2006).

An endosystem, which the research points out as the core of a system, merges with a microsystem, which is the immediate environment a student gets involved in the process of education and health care practice. Bronfenbrenner's emphasizes that when analyzing a microsystem, the full interpersonal system operating in the given setting must be taken into account as this system typically includes all the participants present (including the researcher) and their reciprocal relations (Bronfenbrenner, 1979, Proposition D).

Bronfenbrenner defines four general types of interrelations between two or more settings/environments in which the developing person/ a student becomes an active participant during the process of education and health care practice. He proposes the following interconnections:

1) multi-setting participation;

2) indirect linkage;

3) interesting communications;

4) interesting knowledge.

By taking part in different education and health care practice environments, a student in the process of education and health care practice will have positive developmental effects formed as a result of different interconnections, for example, through international cooperation and student exchange programmes. Different environments/ settings fit into cultural and subcultural contexts and will vary as to their ethnicity, social class, religion, age group or other background factors. Students will thus benefit from such developmental experience, but their capacity to profit will vary directly as a function of the number of transcontextual dyads, across a variety of settings, in which students in their process of education and health care practice have participated prior to that experience (Bronfenbrenner, 1979, Definition 4, Hypothesis 31).

A macrosystem should be understood as a system with a wider ecological context situated furthest away from the immediate experience of students in the process of education and health care practice. At this level, different social factors are involved in the socialization process of a person.

\section{Deep Ecology and Ecosophy}

The principles of the ecological approach analyze the concept of ecology and deep ecology and their importance in education and health care. The principles of the ecological approach are systemically founded and linked into the ideas of the eight-point platform of deep ecology and ecosophy. The characteristics of the principles of the ecological approach correspond to the criteria of the formation and development of the ecological consciousness in everyday life activities and in the process of education and health care.

Deep ecology and ecosophy makes the philosophical and theoretical foundation for the formation and development process of the ecological approach in education and health care. Compared to other prominent theories, deep ecology has not crystallized into a complete system. Deep ecological thinking and ecosophy is a process without end. 
Arne Naess' by an ecosophy mean a philosophy of ecological harmony or equilibrium. A philosophy as a kind of Sofia (or) wisdom, is openly normative, it contains norms, rules, postulates, value priority announcements and hypotheses concerning the state of affairs in our universe. Wisdom is policy wisdom, prescription, not only scientific description and prediction. The details of an ecosophy will show many variations due to significant differences concerning not only the 'facts' of pollution, resources, population, etc. but also value priorities (Drengson, Inoue, 1995; Salite, 1998, 2008).

It is rather a set of prescient hints about the real connections and relations in society, culture and nature. These hints are to environmental philosophy as a tree trunk is to its roots and branches (Rothenberg, 1987).

Ecological wisdom (ecosophy) in education promotes sustainable development and, as an outcome of the learning process, provides ecological knowledge, ecological skills, as well as forms and develops the ecological consciousness in order to emphasize morality and spirituality, which are distinctive human characteristics. It is a knowledge that is deeper than ordinary knowing. Ecological Wisdom is a deeper knowing, a wisdom that can discern the interrelationship of the different components of life as the organisms to their environment which is the totality of all that humans do to maintain and support civilization and societies, including but not limited to the environment. Naess thought it very important that nowadays knowledge and intellectual abilities are highly appreciated as it is our intellectual capacity and abilities that, clearer than anything else, define our privileged and unique position we, humans, occupy among other living creatures on Earth (Naess, 1991; Naess, Haukeland, 2008).

\section{The Principles of the Ecological Approach in Education and Health Care}

The purpose of introducing the ecological approach in education is not to reform educational institutions, but rather transform them so that human relationships and relationships in humanity in general would be, subsequently, greatly harmonized. By combining and consolidating the best alternatives from different theories and practices with a holistic perspective, the ecological approach will develop the unique potential of each and every student. The ecological approach in education does not follow a particular ideology. It is an open-ended continuous attempt to apprehend the complexity and wholeness in a life of a human. Knowledge about the accurate and precise content of nature leads us to a conclusion that change is necessary in education and health care. The often-cited eight-point platform developed by Naess. Sessions could make a new beginning for the ethics of a new practice in health care (Næss \& Haukeland, 2008). The principles of the ecological approach are in line with the characteristics of the quality education and quality health care in the view of the ecological approach.

The principles of the ecological approach in education and health care have been developed in line with the trends in education for sustainable development (Salite, 2008). They are systemically founded on the model of the process-person-context-time system and linked into the ideas of the eight-point platform of deep ecology and ecosophy. The characteristics of the principles of the ecological approach correspond to the criteria of the formation and development of the ecological consciousness in everyday life activities and in the process of education and health care. 


\section{growth \\ 1. The principle of developing the ability to think and performance and experience}

By making independent decisions, students raise their awareness of being developing/ growing spiritual beings in an ecosystem; the knowledge acquired in the process of cognition and learning gives the sense of satisfaction, stimulates the ability to think, enhances reflection and critical thinking; the knowledge-based skills/abilities further enrich the experience and performance in everyday life activities and health care process.

\section{The principle of responsibility}

Ongoing process of self-knowing, responsible and congruent, conduct and performance through functioning, and integrating into social, educational and health care multidimensional environment.

\section{The principle of transformation}

Making a conscious choice about the existence or lack of $I$ and We according to the given situation and reaching the highest possible potential in the development of $I$ freedom.

4. The principle of being aware of the cause-and-effect principle, safety advocacy, and promoting wellness

Being aware of the existence of a global environmental crisis as a result of human activities and practices as a threat to humanity's wellness in the future generations; solving environmental issues, protecting and sustaining the environment in everyday life activities and health care in a democratic and constructive way, primarily advocating universal safety in different dimensions of wellness or significant fields of life, showing respect to religious and cultural diversity in multi-level communication environments, accepting pluralism, maintaining/sustaining wellness in dyads, triads and tetrads and etc.

5. The principle of the unity and wholeness of the core values in education and bealth care

By active participation in the processes of developing society wellness and maintaining sustainability of the environment, students adjust/attune their feelings and the core values in education and health care process.

This all relates to several aspects of the process-person-context-time system, for example, a process and a person or a living being in an ecological setting (Bronfenbrenner \& Morris, 2006; Tudge, \& Mokrova et. al., 2009). The defined principles of the ecological approach complement the code of ethics of students and integrate the criteria of the ecological consciousness into a global systemic view as a sustainability/sustainable development process of a spiritual harmonious being in an ecosystem.

\section{The Content Analysis of Students Essays during the Course of the Ecological Approach in Patient Care}

The ecological approach of cooperating with others, may create an individual lifelong learning plan to keep accumulating new knowledge, skills and communication strategies. This will add to the existing range of talents and thus promote informal education. In the study process during the course of the Ecological Approach in Patient Care, students accumulate new information, as well as recognize and consolidate their 
previously obtained knowledge through active participation. The learning process during the course is in line with the views of Egon Guba and Yvonne Lincoln who thinks that constructivism also includes also hermeneutic and dialectic methodology. This approach reconstructs the experience of the respondents in relation to their perception of the social world (Guba, \& Lincoln, 2005). Personality is viewed as a factor that can explain human behavior and predict their behavior in the acts of social interaction. When describing characteristics of a particular personality, we should put them in specific cultural, historical and attitudinal conditions (Burr, 1995).

The aim of the content analysis is to empirically test the principles of the ecological approach and the ecological competence model in education and health care.

\section{General Guidelines and Organization of the Content Analysis}

The AQUAD 7 (The Analysis of Qualitative Data) programme has been used for the content analysis of the essays written by the students of the study programmes of Nursing and Medicine on completing the course of The Ecological Approach in Patient Care. G. Huber and M. Cooney point to the wide possibilities this programme offers in describing the obtained data, finding linkages and implicating and creating a datagrounded theory (Cooney, 2010; Huber, \& Gürtler, 2004).

Qualitative content analysis is traditionally considered a verifiable research method. It is both formal and systematic, and the variables are expressed in a structured way so that they can be counted by applying quantitative content analysis. This research method is applied in cases when it is necessary to count words to find out how often they appear or are used in the text answering the questions "How will the obtained numbers contribute to the research?" This approach gives a possibility to discover topics or themes after counting the frequency or how many times and what appeared in the text and, most often, it all comes from the surface data (Braun, \& Clarke, 2006).

The content analysis applies a previously developed code system to identify specific units, objective and actual/ factual data (Hodder, 2000).

The qualitative research method includes specific methodology and laws, which allows obtaining credible and valid results and the outcome is considered to be an independent, full and complete study (Denzin, \& Lincoln, 2005).

John Schostak describes the credibility of the data analysis of qualitative research as a process - how accurately the researcher has performed different procedures to come to conclusions, whereas the validity of the study depends on the consequent approach of the researcher in combining different methods and techniques in the course of the research (Schostak, 2005).

In the process of analyzing qualitative research data, the researcher and participants construct the social reality attaching importance to it. Malcolm Williamson and John Hallberg describe such an approach as naturalistic or interpretative. It points to the fact that qualitative research will always have somewhat subjective characteristics and its results will only be attributed to the particular group of participants and specific external conditions (Hallberg, 2006; Williamson, 2006).

In the course of the research, AQUAD 7 program helps to structuralize information and create conceptual codes that are consistent with the theoretical framework for the process of the formation and development of the ecological consciousness and ecological competence of students. 
The chosen categories that become codes and the chosen data sectors for coding that become segments make the essence of the content analysis of student essays. Huber is of the opinion that a single entry of the code in the file is already sufficient evidence. The sequence of the research strategy is not determined; it can easily overlap and be repeated several times as the qualitative research is characterized by non-linear nature. As Figure 3 shows, two strategies - differentiation and generalization are simultaneously applied for analyzing data (Huber, \& Gürtler 2013).

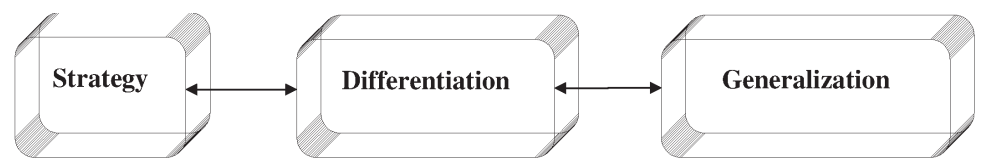

Figure 3. Differentiation and generalization - context for the research strategy

The content analysis of qualitative research includes three steps:

1) data coding;

2) finding linkages;

3) comparison.

Parallel to the differentiation strategy, the whole text of student essays was coded, which helped to highlight the content load of the codes. The codes allowed describing the general conformity of the content of the study course of The Ecological Approach to Patient Care to the basic concepts. The most common and distinctive frequency codes helped to create metacodes in line with the requirements for the content of the student essays. They were asked to write about:

- gains for personal growth;

- gains for professional development;

- the relevance of the course in health care.

\section{Design of the content analysis}

- analysis of student essays in AQUAD 7 programme in line with the criteria for the development of the ecological consciousness and the theoretical building blocks of the research design for the development of the principles of the ecological approach and the ecological competence: education for sustainable development, sustainability/sustainable development, the ecology of human development, deep ecology and ecosophy.

Characteristics of the research group

- Developer and lecturer of the study course of The Ecological Approach in Patient Care;

- Leading researcher, Doctor of Pedagogy of the Faculty of Education, Psychology and Art of The University of Latvia;

- Students of Master's programme in Pedagogy of the University of Latvia.

Choice and characteristics of the research participants

When analyzing the student essays written on completing the course of the Ecological Approach in Patient Care and choosing them for the research and content analysis, Harvey Russell Bernard's approach was used focusing on those respondents who were informed and had obtained knowledge on the topics included in the study course (Bernard, 2006). 


\section{Questions for the Content Analysis}

1) How does the course of The Ecological Approach in Patient Care form the ecological consciousness and develop the ecological competence is order to introduce/ implement the ecological approach in social, educational and health care environment?

2) How does the course of The Ecological Approach in Patient Care demonstrate and ensure the consistency with the knowledge about the basic theoretical building blocks of the research design for the formation and development of the principles of the ecological approach and the ecological competence: sustainability/sustainable development, the ecology of human development, deep ecology and ecosophy?

\section{Thematic Analysis of the Student Essays on Completing the Study Course of the Ecological Approach in Patient Care}

One of the triangulation methods was used in the narrative analysis of the student essays on completing the course of The Ecological Approach in Patient Care. It was given special importance with an aim to identify and justify the formation and development process of the ecological consciousness and the ecological competence.

In the process of the content analysis student essays were analyzed in line with the theoretical justification to determine the categories and that were fully consistent with the previously developed codes. Conceptual relationship among codes relate to the aims and objectives of the study course programme and is in line with the theoretical justification of the criteria of the ecological consciousness and the components of the ecological competence.

Several scholars admit that the main aim of the data-grounded theory is to develop a new theory that would allow for creating a new model practically based and grounded on the data alone (Huber, \& Gürtler, 2004; Hallberg, 2006; Walker, 2006; Cooney, 2010). The developed concepts in the grounded theory are based on specific determined relationship among phrases/ utterances that all together make a conceptual framework and the whole set best describes the researched phenomenon.

The grounded theory should be consistent with the obtained data and it has to provide an appropriate description of the researched phenomenon. The identified categories should be in line with and should describe the data. They should not agree with the previously adopted concepts. It is desirable to reflect on the data, check their consistency to the gathered information by performing alternative interpretations (Hallberg, 2006).

The First Cycle of the Content Analysis

Looking into the content of the student essays as a representation of utterances pronounced with an aim to read them, study them, identify and interpret them in line with the knowledge gained during the study course of The Ecological Approach in Patient Care.

\section{The Second Cycle of the Content Analysis}

A repeated analysis of essays leads to a pilot analysis of the essay content in line with the gained insights. The research group selected 30 student essays by applying analytical induction that includes several cycles of content analysis. 


\section{Content units in student essays:}

- Personality development and systemic thinking;

- Living in harmony and development from I-Ego to I-Eco;

- Professional development;

- Professional empathy;

- Health care;

- Holism and holistic approach.

The chosen categories (codes) are consistent with the obtained knowledge in the study course of The Ecological Approach in Patient Care and show how relevant they are for personality development, professional growth, as well as in the process of the formation and development of the ecological consciousness and ecological competence.

By analyzing 30 first and second year student essays with AQUAD 7 programme, the aim of the research group was to find relevant statements and develop content units for appropriate categories (codes) that were identified in the process of analyzing the essay content. The participants of the research group should agree on their consistency and conformity (Figure 4).

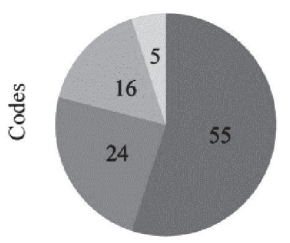

- Holistic approach

Attitude towards nature

Everyday attitude

Attitude to life

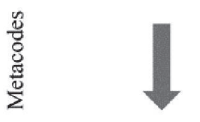

Attitude

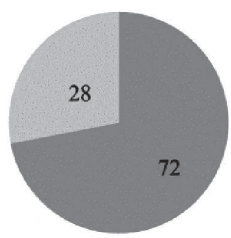

A human being as a value

- Life as a value

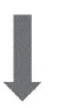

Values

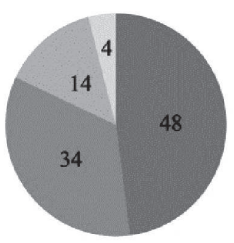

- Personality development

- Cultivation of thinking

- Living in harmony

Transformation from I-ego to I-eco

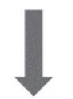

Personality development

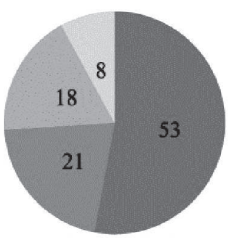

- Professional development

- Professional empathy

Work in a health care team

Professional identity

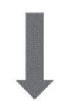

Professional development

Figure 4. Content analysis of student essays according to the code system (\%) creating concepts or meta codes in respective categories

A holistic approach in 30 essays (55\%) could be identified as a desire to see all the ongoing processes in a wider perspective and take part in them; attitude to nature is mentioned in 13 (24\%) essays, daily attitude - 9 (16\%) essays, attitude to life $-3(5 \%)$ essays - these codes relate to the metacode of attitude and are traced in $55(20 \%)$ essays; a human being as a value appears in 23 essays (72\%); life as a value $-9(28 \%)$ essays - these codes fall under the metacode of values and are traced in $32(11 \%)$ essays; personality development - 50 (48\%) essays, developing the - 35 (34\%), living in harmony - $15(14 \%)$, development from I-Ego to I-Eco-4 (4\%) essays - these codes relate to the metacode of personality development and are mentioned in $104(37 \%)$ essays; professional development is mentioned in 47 (53\%) essays, professional empathy $19(21 \%)$, work in a health care team $-16(18 \%)$, professional identity is mentioned in $7(8 \%)$ essays; self - awareness in the profession of a medical nurse and physician 
assistant is relatively low and appears in very few essays. However, there are essays that point to the importance of a professional identity. Codes that relate to the metacode of professional development can be identified in 32 essays (89\%). The content analysis of the essays shows that the least emphasized and least appreciated categories in numbers and percentage suggest that the concept of value in personality and professional development is obviously just being formed and developed.

\section{The Third Cycle of the Content Analysis}

A repeated coding of the content of the student essays in the context of the AQUAD 7 programme with an aim to find out conceptual consistency to the basic theoretical building blocks of the research design for the formation and development of the principles of the ecological approach and the ecological competence, which are - education for sustainable development; the ecology of human development, deep ecology and ecosophy, in order to analyze how the ecological competence of students is being formed and developed.

According to Strauss and Corbin, it is the theory grounded in the subject and is characterized by the fact that it develops as a result of the interrelation of the data when a group of researchers gather, analyse, systematize and select data (Strauss, Corbin, 1998).

Selected content categories (codes) are conceptually linked to Bronfenbrenners ecology of human development, Naess' deep ecology or ecosophy and UNESCO's five pillars of education for sustainable development (Table 1, Figure 5).

Table 1

The Basic Theoretical Building Blocks for the Development of the Principles of the Ecological Approach and the Ecological Competence

\begin{tabular}{|c|c|}
\hline $\begin{array}{c}\text { The basic theoretical building blocks } \\
\text { of the research design }\end{array}$ & Content codes \\
\hline \multirow[t]{4}{*}{ Ecology of human development } & Process \\
\hline & Person \\
\hline & Context \\
\hline & Time \\
\hline \multirow{4}{*}{ Deep ecology and ecosophy } & human being as a value \\
\hline & attitude to life \\
\hline & life quality \\
\hline & abundance and diversity \\
\hline \multirow{5}{*}{ Education for sustainable development } & learning to know \\
\hline & learning to do \\
\hline & learning to live together \\
\hline & learning to be \\
\hline & learning to transform oneself and society \\
\hline
\end{tabular}




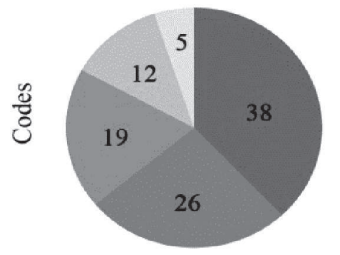

- Professional development

Process

Context

Time

Personality development

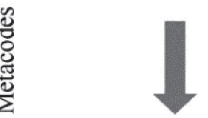

Ecology

of human development

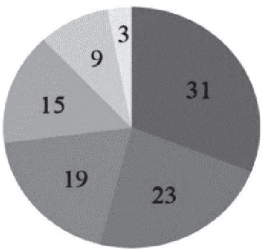

- Abundance and diversity

- A human being as a value

- Attitude to a human being

- Life quality

- Life as a value

Attitude to life

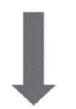

Deep ecology or ecosophy

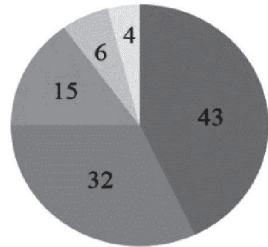

- Learning to know

- Learning to do

= Learning to live together

Learning to be

Learning to transform oneself and society

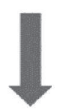

Education for sustainable development

Figure 5. A repeated content analysis of student essays according to the code system $(\%)$ creating concepts or meta-codes in line with the basic theoretical building blocks

The analysis of the collected data gives the following findings: professional development is mentioned in $50(38 \%)$ essays, process - in $35(26 \%)$ essays, context -25 $(19 \%)$, time $-16(12 \%)$, personality development $-7(5 \%)$ essays - these codes relate to the metacode of the ecology of human development (39\%); wealth and diversity are mentioned in $30(31 \%)$ essays, a human being as a value $-23(23 \%)$, attitude to a human being $-19(19 \%)$, life quality - $15(15 \%)$ essays, life as a value $-9(9 \%)$, attitude to life $-3(3 \%)$ - these codes refer to the metacode of deep ecology and ecosophy and are mentioned in $99(29 \%)$ essays; learning to know is traced in $47(43 \%)$ essays, learning to do $-35(32 \%)$, learning to live together $-16(15 \%)$, learning to be $-7(6 \%)$, learning to transform oneself and society $-4(4 \%)$ essays - these codes relate to the metacode of education for sustainable education and are mentioned in $109(32 \%)$ essays.

Table 2

Examples of Content Units from Student Essays According to the Categories (codes)

\begin{tabular}{|c|c|}
\hline Examples of content units from student essays & $\begin{array}{l}\text { Categories } \\
\text { (codes) }\end{array}$ \\
\hline (...) ecology includes education, medicine and human relationship. & \multirow{3}{*}{$\begin{array}{l}\text { Personality } \\
\text { development }\end{array}$} \\
\hline (...) education and knowledge help people judge more objectively. & \\
\hline (...) we are powerless without knowledge. & \\
\hline (...) lectures have been encouraging us to THINK. & \multirow{2}{*}{$\begin{array}{l}\text { Cultivation } \\
\text { of thinking }\end{array}$} \\
\hline $\begin{array}{l}\text { (...) thoughts and emotions have deep impact on the physical world and } \\
\text { human health. }\end{array}$ & \\
\hline $\begin{array}{l}\text { (...) we have all come into this world with a specific purpose and mission; } \\
\text { we must think about ourselves and also consider everybody else who } \\
\text { dwells in this house. }\end{array}$ & $\begin{array}{l}\text { Living in } \\
\text { harmony }\end{array}$ \\
\hline
\end{tabular}


Sequel to Table 1.

(...) we are not indifferent to the dwellers of our house and we are ready to help and protect others should the need arise.

(...) we must learn to live not only for ourselves; we must think about others around us; we must be tolerant and show empathy to other people because we complement each other.

(...) people should think and reflect on how we treat each other, how we treat nature and the environment we live in.

(...) I would like to apply the ecological principles and their main idea in practice.

(...) health, environment and health care are closely interrelated.

(...) from now on, practice makes it perfect.

(...) medical nurses should be fully committed without any make believe, without any negative thinking putting their heart and soul into helping patients as much as possible in line with their knowledge and competence and considering the patient's attitude towards themselves.

(...) we don't have to love all patients but we must take care of them.

(...) we must work in a team because one person cannot provide wholesome health care.

(...) a health care team should provide holistic care.

(...) team work brings the sense of satisfaction for a job well-done.

(...) the ecological approach creates the sense of belonging to the profession.

(...) it is about time for us, young medical nurses, start a change; we have all that is necessary to practically implement the ecological approach in patient care.

(...) the profession of a medical nurse should be a calling and the sense of mission.

(...) When I reflect on what has been covered in the course I have a desire to change the world.

(...) we can make the world brighter, safer, healthier and more colourful.

Professional

development

Let's do it together! Let's do it with passion!

(...) this is an art of treating the world as your home.

(...) there is always a compromise - we can - not only destroy and take, but also give and restore.

Professional

empathy

Work in a

bealth care team

(...) human beings with their ever increasing needs and demands are not more important than other members of the surrounding environment.

(...) we should take care of others in the same way as we take care of ourselves - not only by helping but also by supporting, encouraging, praising, comforting and respecting others as our equals.

Holistic

approach

Professional

identity

(...) with the ecological approach, I can show respect to others and respect myself.

(...) every living creature is a unique and irreplaceable value.

(...) it helps us realize that every living creature is unique, special and

Attitude to life valuable.

(...) the range of values of a person enhances our understanding of the importance of environment and the role of humans in it.

Attitude

towards nature

(...) beingness is important; it is not just automatic and mechanic.

(...) the life of a person is the greatest treasure of medical professionals.

(...) every living creature is like a cogwheel in clockwork.

Every day

attitude

A human being as a value

Life as a value 


\section{Conclusions}

Analyzing the content of student essays, the respective chosen categories (codes) characterize the concepts (metacodes) that are consistent with the basic theoretical building blocks of the research: the ecology of human development 133 (39\%), education for sustainable development 109 (32\%), deep ecology or ecosophy 99 (29\%).

The categories or codes identified by the research group characterize the theoretical components of the formation and development process of the ecological consciousness and ecological competence.

Examples from the student essays analyzed in the research are consistent with the categories and content codes that attest to the knowledge obtained in the study process with an aim of forming and developing the ecological consciousness and ecological competence in social, educational and health care environment.

The content analysis of student essays is in the theory grounded qualitative research that, in line with the concepts (metacodes), describes the process of the formation and development of the ecological consciousness and ecological competence, which is grounded in knowledge and integrates the principles of the ecological approach in education and health care.

The content analysis of the essays clearly demonstrates that the concept of value in personality and professional development is obviously just being formed and developed. These categories are least emphasized and least appreciated in numbers and percentage.

\section{Discussion}

Education and health care nowadays are related to global processes. By developing theories, research and evidence-based health care, it keeps developing and creating new knowledge and discoveries and contributing to progress. The concepts process - personcontext-time applied in the bio-ecological theory are equivalent to the most important concepts of nursing theories, such as person, setting, interrelation, adaptation etc.

Dyads, triads, tetrads etc. in the process of education and health care create and develop mutual trust, cooperation and emotional support. They maintain the balance of power in subject-subject relationships promoting the implementation of the pillars of education for sustainable development (ESD) learning to be, learning to live together and learning to transform oneself and society in education and health care.

The essence of the principles of the ecological approach in education and health care is to expand the duty ethics that dominates the professional code of ethics of health care professionals. This highlights the importance of a value-oriented lifestyle and systemic thinking. That makes essential conditions for the formation and development of ecocentric ecological consciousness and ecological wisdom in social, educational and health care environments.

The study course: The Ecological Approach to Patient Care is in line with the basic theoretical building blocks of the research; the identified categories or codes characterize the theoretical components of the process of the formation and development of the ecological consciousness and ecological competence of students. The examples from the student essays correspond to the categories and the content codes that attest to the knowledge acquired during the course with an aim to form and develop the ecological consciousness and ecological competence in social, educational and health care environ- 
ment. According to the characteristics of A. Strauss and G. Corbin, the content analysis of students' essays is theory grounded in the subject (Strauss, \& Corbin, 1998).

Sustainability/sustainable development in education and health care should be understood in the context of globalization and global processes, which are described as both a process and a condition in the system, the power, the era, which is the foundation of the changing shape of human interaction. Manfred Steger called that globalisation is a dynamic process, which is best described by the concept of development, or formation according to a particular model (Steger, 2009).

The explanation of the concept of sustainability/sustainable development focuses on such concepts as - change of attitude, environmental consciousness, behaviour, responsibility, and values, which is the principle of ecological approach in education and health care practice. In order to understand the complex sustainability/sustainable development environmental change of the system, we need to evaluate the improvement process in education and health care practice.

\section{References}

Bakutytè, R., Ušeckienè, L., \& Iliško, Dz. (2016). The development of implementation of learner - centered assessment in pedagogical requalification studies. Social Welfare Interdisciplinary Approach, 56-62. doi: 10.21277/sw.v2i6.264.

Bernard, H. R. (2006). Research methods in anthropology: qualitative and quantitative approaches. Lanham, MD: Alta Mira Press.

Braun, V., \& Clarke, V. (2006). Using thematic analysis in psychology. Qualitative Research in Psychology, 3(2), 77-101.

Broks, A. (2000). Systemology of Education. Riga: RaKa.

Bronfenbrenner, U., \& Morris, P. A. (2006). The bio ecological model of human development. In R. M. Lerner \& W. Damon (Eds.) Theoretical models of human development. Handbook of Child Psychology. (pp. 793-828.). New York: Wiley \& Sons.

Bronfenbrenner, U. (1979). The ecology of human development. Experiments by nature and design. Cambridge: MA Harvard University Press.

Burr, V. (1995). An introduction to social constructions. London: Rout ledge.

Cooney, A. (2010). Choosing between Glaser and Strauss: an example. Nurse Research, 17 (4), 18-28.

Denzin, N. K., \& Lincoln,Y.S. (2005). ( ${ }^{\text {rd }}$ Ed.). The SAGE hand book of qualitative research. Thousandd Oaks, California: Sage Publications.

Drengson, A., \& Inoue, Y. (1995). (Eds.). The deep ecology movement: An introductory anthology. Berkeley: North Atlantic Publishers.

Guba, E. G., \& Lincoln, Y. S. (2005). Paradigmatic controversies, contradictions, and emerging confluences. In N. K. Denzin \& Y. S. Lincoln (Eds.), Handbook of qualitative research ( $3^{\text {rd }}$ Ed.), (pp. 191-216.). Thousand Oaks, CA: Sage.

Hallberg, L. (2006). The core category of grounded theory: Making constant comparisons. International Journal of Qualitative Studies on Health and Well-being, 1(3), 141148.

Hodder, I. (2000). ( $\left.2^{\text {nd }} E d.\right)$. The interpretations of documents and material culture. Handbook of Qualitative Research. Thousand Oaks, CA: Sage Publications, 703715. 
Huber, G., \& Gürtler, L. (2013). AQUAD 7. Manual: the analysis of qualitative data. Tübingen: Softwarevertrieb Günter Huber. Retrieved from http://www.aquad.de/ materials/manual_aquad7/manual-e.pdf

Huber, G.L., \& Gürtler, L. (2004). AQUAD six: Manual for the analysis of qualitative data. Tübingen: Ingeborg Huber Verlag.

Lerner, R. M. (2006). Developmental science, developmental systems, and contemporary theories of human development. In W. Damon \& R. M. Lerner (Eds.). Handbook of child psychology (pp. 1-17). Hoboken, NJ: John Wiley \& Sons.

Mollenhauer, K. (1973). Education and emancipation. München: Juventa.

Næss, A., \& Haukeland, P.I. (2008). Life's philosophy: reason \& feeling in a deeper world. Athens GA, University of Georgia press.

Naess, A. (1991). Ecology, community and lifestyle. London: Cambridge.

Rothenberg, D. (1996). No world but in things: The poetry of Naess's concept contents. Inquiry: An Interdisciplinary Journal of Philosophy and the Social Sciences, 39(2), 255-272.

Salìte, I., Drelinga, E., Iliško, Dz., Zariņa, S., \& Oḷehnoviča, E. (2016). Sustainability from the transdisciplinary perspective: An action research strategy for continuing education course development. Journal of Teacher Education for Sustainability, $17(2), 135-153$.

Salite, I. (2008). Educational action research for sustainability: Constructing a vision for the future in teacher education. Journal of Teacher Education for Sustainability, $10,5-17$.

Salite, I. (1998). An eco-centric paradigm: An important tool for teachers of environmental education. Australian Journal of Environmental Education, 14, 81-85.

Schostak, J. F. (2002). Understanding, designing and conducting qualitative research in Education: framing the Project. Buckingham; Philadelphia: Open University Press.

Steger, B. M. (2009). (2 ${ }^{\text {nd }}$ Ed.). Globalization: a very short introduction. New York: Oxford University Press.

Strauss, A. L., \& Corbin, J. (1998). Basics of qualitative research: Techniques and procedures for Developing grounded theory: second edition. Thousand Oaks, CA: Sage.

Tudge, J., Mokrova, I., Hatfield, B., \& Karnik, R. (2009). (Ed.). Uses and misuses of Bronfenbrenner's bioeclogical theory of human development. Journal of Family Theory \& Review, 198-210.

UNESCO (2002). Education, public awareness and training for sustainability: Input to the Report of the Secretary General to the Second Preparatory Session for the World Summit on Sustainable Development. UNESCO, Paris. Retrieved from: http://www.earthcharter.org

Walker, D. (2006).Grounded theory: An exploration of process and procedure. Qualitative Health Research, 16(4), 547-558.

Williamson, K. (2006). Research in constructivist frameworks using ethnographic techniques, Library Trends, 55(1), 83-101.

Correspondence concerning this article should be addressed to Ruta Renigere, Riga Medical College of the University of Latvia, Hipokrāta street 1, Rīga, Latvia, LV-1079. Email: rutarenigere@inbox.lv 